\title{
Audiowizualne usługi medialne w świetle dyrektywy 2007/65/WE Parlamentu Europejskiego i Rady
}

Elektroniczne środki przekazu należą do tych dziedzin, które dzięki stałemu postępowi techniki rozwijają się szczególnie dynamicznie. Prawo, także europejskie, z ledwością podąża za stałymi zmianami i przekształceniami, jakie pojawiają się w tym obszarze. Niemniej od początku Wspólnoty Europejskie, a obecnie Unia, podejmują próbę zakreślenia ogólnych ram funkcjonowania radiofonii, telewizji, internetu, a ostatnio także usług medialnych. Trud regulacji w tej płaszczyźnie podejmowała także Rada Europy, w szczególności tworząc Europejską Konwencję o Telewizji Ponadgranicz$n j^{1}$. Konwencja ta zawiera istotne standardy w obszarze ponadgranicznego przekazu telewizyjnego, w znacznym stopniu zbieżne z postanowieniami Wspólnotowej Dyrektywy „Telewizja bez granic"2. W systemie prawnym Rady Europy problematyki funkcjonowania telewizji dotyczy szereg zaleceń Komitetu Ministrów Rady Europy, kierowanych do państw członkowskich ${ }^{3}$, a także uchwał i zaleceń przyjmowanych przez Zgromadzenie Parlamentarne Rady Europy. Istotne znaczenie mają także postanowienia Europejskich Konferencji Ministerialnych dotyczące polityki w dziedzinie mediów masowych ${ }^{4}$.

Warto przypomnieć, że już dyrektywą Rady Unii Europejskiej z 3 października 1989 roku postanowiono skoordynować przepisy ustawowe, wykonawcze i administracyjne państw członkowskich dotyczące wykonywania działalności transmisyjnej ${ }^{5}$. Wspomnianą dyrektywą umożliwiono koordynację prawa i praktyki państw członkowskich w zakresie produkcji i emisji programów telewizyjnych ${ }^{6}$. Komisja Europejska

1 Dz. U. 1995, Nr 46, poz. 238. Konwencja sporządzona w Strasburgu 5 maja 1989 roku została ratyfikowana przez Polskę 15 marca 1994 r. Por. Dz. U. 1995, Nr 32, poz. 160.

2 R. Wallace, D. Goldberg, Television Broadcasting. The Community's Response, „Common Market Law Review” 1989, nr 4, s. 724. Zob. także C. Milk, Wolność radia i telewizji w świetle Europejskiej Konwencji i prawa polskiego, „Państwo i Prawo” 1993, z. 10, s. 22.

3 Omawia je szczegółowo A. Jaskiernia, Prawo do wypowiedzi w świetle standardów Rady Europy, „Państwo i Prawo” 2006, nr 6, s. 46. Por. także Rada Europy, a problemy mediów masowych, Warszawa 2002, passim.

4 Szerzej w tym przedmiocie A. Jaskiernia, Publiczne media elektroniczne w Europie, Warszawa 2006, s. 76 i n.; tegoż, Rola Rady Europy w dziedzinie mediów masowych, „Studia Medioznawcze” 2001, nr 1, s. 75.

5 Dyrektywa Rady 89/552 EWG z 3 października 1989 r. w sprawie koordynacji niektórych przypisów ustawowych, wykonawczych i administracyjnych państw członkowskich dotyczących wykonywania telewizyjnej działalności transmisyjnej (Dz. U. L. 298 z 17 października 1989 r., s. 23). Wspomniana dyrektywa została po kilku latach zmieniona dyrektywą 97/36/WE (Dz. U. L. 2002 z 30 lipca 1997 r., s. 60).

6 K. Doktorowicz, ,, Telewizja bez granic”- europejskie regulacje w dziedzinie komunikowania, w: K. Doktorowicz, W. Dudek (red.), Międzynarodowe regulacje środków przekazu, Katowice 1992, s. 42. 
reagowała na bieżąco na problemy wynikające z realizacji tej dyrektywy, szereg jej niezbyt jasnych postanowień interpretować musiał Trybunał Sprawiedliwości ${ }^{7}$. W systemie wspólnotowym, rzuca się w oczy olbrzymie zainteresowanie dla nowych technologii informacyjnych. Warto pamiętać, że Parlament Europejski i Rada przyjęły w dziedzinie telekomunikacji pakiet regulacji obejmujących Dyrektywę Ramową oraz dyrektywy dotyczące dostępu, zezwoleń, usług powszechnych i prywatności w komunikacji elektronicznej ${ }^{8}$. Wpisuje się w to także przyjęcie przez Wspólnotę Europejską tzw. Dyrektyw Nowego Podejścia9. Pamiętać należy, że w Protokole o Publicznej Działalności Emisyjnej, towarzyszącemu Traktatowi Amsterdamskiemu, zagwarantowano istnienie telewizji publicznej, wypełniającej misję publiczną na zasadach określonych przez państwa członkowskie ${ }^{10}$.

Przyjęcie wspomnianej wyżej Dyrektywy Rady 89/552/EWG i związane z tą dyrektywą orzecznictwo, bardzo mocno przekształciło europejski system publicznej działalności emisyjnej ${ }^{11}$. Dyrektywa ta była jednak dość jednoznacznie krytykowana, przy czym wskazywano, że jej treść nie odpowiada aktualnie stosowanym i planowanym w przyszłości standardom odnoszącym się do działalności telewizyjnej. Wskazywano przy tym, iż pomija ona możliwości, jakie niesie ze sobą system cyfrowego rozpowszechniania programów ${ }^{12}$. Wkrótce jednak okazało się, iż nowe technologie transmitowania audiowizualnych usług medialnych sprawiły, że niezbędnym stało się dostosowanie ram regulacyjnych w taki sposób, aby mogły one uwzględnić z jednej strony wpływ zmian strukturalnych w zakresie rozpowszechnienia technologii informacyjno-komunikacyjnych i rozwoju technologicznego na prowadzenie działalności gospodarczej w zakresie usług audiowizualnych, z drugiej zaś strony, aby mogły zapewnić optymalne warunki konkurencyjności i pewność prawną w europejskich sektorach: technologii informacyjnej oraz mediów. Okazało się także koniecznym zapewnienie poszanowania różnorodności kulturowej i językowej świadczonych usług medialnych. Przypomnieć w tym miejscu należy, że w chwili obecnej rozpowszechnianie telewizyjne obejmuje w większości krajów unijnych telewizję analogową i cyfrową, transmisję strumieniową na żywo (live streaming), nadawanie w internecie (webcasting) oraz sekwencyjne udo-

7 J. Snell, De Agostini and the Regulation of Television Broadcasting, „European Business Law Review" 1997, nr 10, s. 223.

8 Zob. W. Gogołek, Technologie informacyjne mediów, Warszawa 2005, s. 19.

9 Dyrektywy: 19/2002 z 7 marca 2002 r. i 58/2002 z 12 lipca 2002 r.

10 Zob. C. Mik, Media masowe weuropejskim prawie wspólnotowym, Toruń 1999, s. 98. Zob. także M. Barańska, Jurysdykcja europejska a polskie rozwiazania prawne w przedmiocie marketingu politycznego, w: Z. Czachór, Standardy europejskie, Wrocław 2001, s. 13 i n. Wspólnoty, a potem Unia dążyły do zdefiniowania tzw. misji publicznej. Zob. w tym przedmiocie J. Skrzypczak, Finansowanie telewizji publicznej a prawo UE, „Za Ekranem” 2004, nr 6, s. 14-15. Starano się także o rozwiązanie problemu koncentracji mediów. Zob. E. Stasiak-Jazukiewicz, Polityka medialna Unii Europejskiej, Warszawa 2005, s. 42; P. Stępka, A. Woźniak, Polityka na rzecz ochrony pluralizmu w mediach na przyktadzie wybranych państw europejskich, „Biuletyn Informacyjny Krajowej Rady Radiofonii i Telewizji", styczeń-czerwiec 2006, s. 44.

11 Zob. w tym przedmiocie A. Jaskiernia, Publiczne media elektroniczne..., s. 116; ibidem, analiza orzecznictwa.

${ }^{12}$ S. van den Bogaert, Dyrektywa Rady Unii Europejskiej o nadawaniu programów telewizyjnych, „Przegląd Ustawodawstwa Gospodarczego” 2004, nr 1, s. 15. 
stępnianie audycji (near-video-on-demand) ${ }^{13}$. W efekcie, Komisja Europejska wystapiła 13 grudnia 2005 r. z propozycją nowelizacji dyrektywy „Telewizja bez granic”, proponując aby nowa dyrektywa objęła swoim zasięgiem linearne usługi audiowizualne (webcasting), jak i wprowadziła minimalne wspólnotowe standardy dla nielinearnych usług audiowizualnych (video-on-demand), a także uelastyczniła uregulowania dotyczące przerywania programów spotami reklamowymi ${ }^{14}$.

Wkrótce jednak okazało się, iż nowe technologie transmitowania audiowizualnych usług medialnych sprawiły, że niezbędnym stało się dostosowanie ram regulacyjnych w taki sposób, aby mogły one uwzględnić z jednej strony wpływ zmian strukturalnych w zakresie rozpowszechnienia technologii informacyjno-komunikacyjnych i rozwoju technologicznego na prowadzenie działalności gospodarczej w zakresie usług audiowizualnych, z drugiej zaś strony, aby mogły zapewnić optymalne warunki konkurencyjności i pewność prawną w europejskich sektorach: technologii informacyjnej oraz mediów. Okazało się także koniecznym zapewnienie poszanowania różnorodności kulturowej i językowej świadczonych usług medialnych. Przypomnieć w tym miejscu należy, że w chwili obecnej rozpowszechnianie telewizyjne obejmuje w większości krajów unijnych telewizję analogową i cyfrową, transmisję strumieniową na żywo (live streaming), nadawanie w internecie (webcasting) oraz sekwencyjne udostępnianie audycji (near-video-on-demand $)^{15}$.

Wypada od razu zauważyć, że pojęcie usług medialnych od dłuższego czasu było używane w doktrynie prawa europejskiego, aczkolwiek nie posiadało swojej definicji legalnej. Ustawodawca europejski świadom był niewątpliwie problemów, jakie pojęcie „audiowizualnych usług medialnych" rodzić musi, chociażby tylko z tego względu, iż terminy: „środki audiowizualne” i „dzieła audiowizualne” są w praktyce różnie definiowane zarówno na gruncie prawa europejskiego, jak i w poszczególnych państwach członkowskich. Spór o zakres przedmiotowy tych terminów toczy się także na gruncie prawa autorskiego, gdyż utwory audiowizualne to dzieła w rozumieniu nie tylko polskiego prawa autorskiego. Dlatego też, zmagając się z tymi trudnościami, Parlament Europejski i Rada w analizowanej w tym miejscu dyrektywie zastrzegły wyraźnie, że pojęcie ,audiowizualnych usług medialnych”, jakim posiłkują się w treści tego aktu normatywnego, odnoszą się jedynie do materii regulowanej w dyrektywie 2007/65/WE z 11 grudnia 2007 r. zmieniającej dyrektywę Rady 89/552/EWG w sprawie koordynacji niektórych przepisów ustawowych, wykonawczych i administracyjnych państw członkowskich dotyczących wykonywania telewizyjnej działalności transmisyjnej. Audiowizualne usługi medialne w rozumieniu dyrektywy z dnia 11 grudnia 2007 r. obejmują środki masowego przekazu jako nośnika informacji, rozrywki i edukacji dla ogółu odbiorców. W dyrektywie podkreślono, że audiowizualne usługi medialne to także han-

13 Usługa wideo na żądanie nie była nigdy traktowana przez ustawodawstwo europejskie jako forma rozpowszechniania telewizyjnego, lecz była traktowana jako audiowizualna usługa medialna na żądanie.

${ }_{14}$ Projekt nowelizacji dyrektywy ,o Telewizji bez granic”, „Biuletyn Informacyjny Krajowej Rady Radiofonii i Telewizji”, styczeń-czerwiec 2006, s. 38.

${ }^{15}$ Usługa wideo na żądanie nie była nigdy traktowana przez ustawodawstwo europejskie jako forma rozpowszechniania telewizyjnego, lecz była traktowana jako audiowizualna usługa medialna na żądanie. 
dlowe przekazy audiowizualne $\mathrm{z}$ wyraźnym jednak wyłączeniem wszelkich form prywatnej korespondencji oraz wiadomości poczty elektronicznej, wysyłanych do ograniczonej liczby odbiorców. Poza obrębem audiowizualnych usług medialnych znalazły się jednak - w świetle postanowień dyrektywy - wszelkie usługi, których celem głównym nie jest dostarczanie audycji, tzn. usług, których głównym celem nie jest przekaz treści audiowizualnej, lecz jedynie częścią uboczną usługi ${ }^{16}$. Jako przykłady usług, które nie mają charakteru audiowizualnych usług medialnych w rozumieniu dyrektywy, ustawodawca europejski wskazał strony internetowe zawierające elementy audiowizualne o charakterze pomocniczym, np. w postaci animowanych elementów graficznych, krótkich spotów reklamowych, a także informacje związane z produktem lub usługą nie będącą usługą audiowizualną. Wyraźnie wyłączono spod zakresu działania dyrektywy gry losowe, w których stawką są pieniądze, w tym loterie, zakłady i usługi hazardowe, a także gry i wyszukiwarki internetowe. W obrębie dyrektywy pozostały jednak przekazy poświęcone samemu hazardowi i samym grom losowym. W praktyce tak określony zakres przedmiotowy audiowizualnych usług medialnych może zrodzić i na pewno zrodzi rozmaite wątpliwości, stając się źródłem sporów i nieporozumień. Wyraźnie wyłączono z zakresu przedmiotowego dyrektywy elektroniczne wersje gazet i czasopism. Pisząc o „elektronicznych wersjach” ustawodawca wyraźnie zajął stanowisko w teoretycznym sporze o to, czy prasa publikowana w internecie jest prasą taką sama, jak prasa drukowana na papierze, opowiadając się za teza, że przekaz elektroniczny jest tylko forma, która nie ma istotniejszego znaczenia, podobnie jak nie ma znaczenia to, czy dziennik bądź czasopismo zostaną wydrukowane na papierze kredowym, czerpanym bądź gazetowym.

Ustawodawca europejski wyraźnie podkreślił, że pojęciem audiowizualnych usług medialnych należy objąć tylko te usługi, które są usługami masowego przekazu - tzn. są przeznaczone do odbioru przez znaczną część ogółu odbiorców i mogą mieć na tę część wyraźny wpływ. I w tym przypadku ustawodawca wyraźnie nadużywa pojęć niedookreślonych mówiąc o „wyraźnym wpływie” i „znacznej części odbiorów”. Samo zresztą pojęcie „usługi” może budzić wątpliwości i dlatego ustawodawca europejski wyraźnie podkreśla, że chce pod tym terminem rozumieć usługi w rozumieniu Traktatu ustanawiającego Wspólnotę Europejską, a więc każdy rodzaj działalności gospodarczej, w tym także działalność przedsiębiorstw świadczących usługi publiczne. Poza obrębem tak pojmowanego pojęcia „usługi” znajdzie się działalność niekomercyjna (ustawodawca mówi o działalności „zasadniczo niekomercyjnej” - podkreślenie moje) i nie stanowiąca konkurencji dla rozpowszechniania telewizyjnego. Do takich przekazów i do takiej działalności zaliczono w dyrektywie prywatne witryny internetowe oraz usługi polegające na dostarczaniu lub dystrybucji treści audiowizualnej, wytworzonej przez prywatnych użytkowników, w celu jej udostępnienia lub wymiany w ramach grup zainteresowań.

Europejski ustawodawca zwrócił uwagę, że cechą audiowizualnych usług medialnych na żądanie jest to, że przyjmują one formy quasi-telewizyjne, tzn. iż są skierowane

16 Zob. Dyrektywa 2007/65/WE pkt 18. Warto zauważyć, że dyrektywa posługuje się terminami niedookreślonymi: „głównym celem”, „częścią uboczną”. W praktyce może to budzić rozliczne wątpliwości. 
do tych samych odbiorców, co przekazy telewizyjne, a ich charakter i sposób dostępu powoduje, że użytkownik ma podstawy do oczekiwania, że zostanie objęty ochroną regulacyjną przez ustawodawcę europejskiego ${ }^{17}$. Tak więc dyrektywa z 11 grudnia $2007 \mathrm{r}$. ma zastosowanie do rozpowszechniania telewizyjnego oraz audycji telewizyjnych, które są udostępniane przez tego samego dostawcę usług medialnych jako audiowizualne usługi medialne na żądanie, tym samym, jak stwierdzono expressis verbis $\mathrm{w}$ dyrektywie, ma ona zastosowanie do przekazów telewizyjnych w ramach tzw. transmisji linearnej. Stwierdzając, że określenie ,audiowizualne” odnosi się do ruchomych obrazów z dźwiękiem lub bez niego, ustawodawca wyraźnie zaznaczył, że pojęciem tym obejmuje „filmy nieme”, ale nie dotyka transmisji dźwiękowej, ani usług radiowych. W dyrektywie skonstatowano, że jakkolwiek głównym celem audiowizualnej usługi medialnej jest dostarczanie audycji, to jednak zakresem takiej usługi obejmuje się także treść przekazywaną w formie tekstu towarzyszącego audycji. Wyraźnie wskazano, że taki charakter będą miały wyświetlane listy dialogowe i elektroniczny przegląd audycji, natomiast nie dotyczy dyrektywa samodzielnych usług tekstowych. Wyraźnie zaznaczono, że dostawca usług medialnych ponosi odpowiedzialność redakcyjną za ich treśćc ${ }^{18}$.

W dyrektywie nałożono na państwa członkowskie powinność szerszego zdefiniowania handlowego przekazu audiowizualnego, zwracając jednak uwagę, że definicja ta nie powinna obejmować emitowanych bezpłatnie ogłoszeń dotyczących usług publicznych oraz akcji charytatywnych. Zauważono także, że w celu stworzenia silnego, konkurencyjnego i zintegrowanego sektora audiowizualnego oraz zwiększenia pluralizmu mediów w całej Europie, należy dostawcę audiowizualnych usług medialnych poddać jurysdykcji wyłącznie jednego państwa członkowskiego, a z pluralizmu informacji uczynić podstawową zasadę Unii Europejskiej. Podkreślono, że dyrektywa dotyczy tylko tych audiowizualnych usług medialnych, które mogą być odbierane bezpośrednio lub pośrednio za pomocą standardowych urządzeń konsumenckich przez widzów w co najmniej jednym państwie członkowskim ${ }^{19}$. Podnosząc, że art. 43 i 48 TWE ustanawiają prawo przedsiębiorczości jako prawo podstawowe, ustawodawca europejski stwierdził, że dostawcy usług medialnych powinni mieć swobodę wyboru państw członkowskich, w których chcą umieścić swoją siedzibę. To stwierdzenie zostało jednak nieco osłabione zastrzeżeniem, iż „na ogół” powinni mieć taką swobodę ${ }^{20}$. Zdając

17 Wydaje się, że stwierdzenie, iż użytkownik oczekuje ochrony regulacyjnej, jest trochę ,na wyrost", aczkolwiek niewątpliwie ustawodawca europejski ma rację co do tego, że użytkownik chciałby mieć pewność, iż jego prawa nie zostaną naruszone przez podmioty świadczące audiowizualne usługi medialne.

18 Ustawodawca europejski wskazał, że państwa będące członkami Unii mogą dokładniej określić zasady odpowiedzialności redakcyjnej podmiotów świadczących usługi audiowizualne. Wyraźnie także stwierdzono, że dyrektywa nie narusza postanowień zawartych w treści dyrektywy 2000/31/WE Parlamentu Europejskiego i Rady w sprawie niektórych aspektów prawnych usług społeczeństwa informacyjnego, w szczególności handlu elektronicznego w ramach rynku wewnętrznego (tzw. Dyrektywa o handlu elektronicznym). Dz. U. L. 178 z 17 lipca 2000 r., s. 1.

19 Potrzebę zdefiniowania pojęcia „standardowe urządzenia konsumenckie” ustawodawca europejski pozostawił właściwym organom krajowym.

20 Warto zauważyć, że Trybunał Sprawiedliwości w Luksemburgu podkreślił, iż „Traktat nie zakazuje przedsiębiorstwu korzystania ze swobody świadczenia usług, jeżeli nie ofiaruje ono usług 
sobie sprawę z trudności, jakie może rodzić stosowanie dyrektywy, ustawodawca europejski podkreślił, że państwa członkowskie muszą mieć możność stosowania do dostawców usług medialnych, podlegających ich jurysdykcji, bardziej szczegółowych i surowszych przepisów we wszystkich tych dziedzinach, których dotyczy dyrektywa. Wskazano także, że w odniesieniu do dostawców usług medialnych państwa Unii winny ze sobą ściśle współpracować, chroniąc w szczególności interesy konsumentów, małoletnich oraz zasady polityki kulturalnej. Jakkolwiek państwa członkowskie moga, jak wskazano w dyrektywie, podejmować działania, które ograniczają swobodę przekazów telewizyjnych, to jednak, zgodnie z utrwalonym orzecznictwem Trybunału Sprawiedliwości, wszelkie odstępstwa od podstawowej zasady, jaką jest swoboda świadczenia usług, będą podlegały wykładni zawężającej ${ }^{21}$.

Ustawodawca europejski zdawał sobie wyraźnie sprawę z faktu, iż dyrektywa spowoduje duże trudności dla regulacji płaszczyzny objętej jej treścią przez ustawodawstwa poszczególnych państw. Zauważył jednak, iż powinny one być przezwyciężone, albo poprzez samoregulację, albo współregulację. Środki te winny służyć osiaggnięciu celów leżących w interesie publicznym w sektorze usług medialnych na rynku audiowizualnym. Pod pojęciem samoregulacji ustawodawca europejski widział rozmaite dobrowolne inicjatywy, pozwalające podmiotom gospodarczym, partnerom społecznym, organizacjom pozarządowym oraz stowarzyszeniom przyjmować wspólne wytyczne. Wskazano, że państwa będące członkami Unii winny uznać rolę, jaką ta samoregulacja może spełniać. Zauważono jednak, że takowa sama regulacja nie może wyręczyć prawodawcy krajowego. Wskazując na współregulację, w dyrektywie podniesiono, że jest ona ogniwem pośrednim między samoregulacją, a działaniami prawodawcy krajowego. Takowa współregulacja winna dopuszczać możliwość interwencji państwa w przypadku, gdy cele współregulacji nie zostaną spełnione. Podkreślając rolę współregulacji i samoregulacji, ustawodawca europejski podkreślił jednak, że dyrektywa nie nakłada na państwa członkowskie obowiązku ustanowienia ani systemu współregulacji, ani tym bardziej systemu samoregulacji.

Twórcy dyrektywy wyraźnie wątpią w to, iż korzystający ze środków przekazu potrafią skutecznie i bezpiecznie korzystać z nich, że będą dokonywać świadomych wyborów i, że potrafią zdawać sobie sprawę z charakteru i treści usług, oraz że będą w stanie korzystać z całego zakresu możliwości stwarzanych przez nowe technologie komunikacyjne. $Z$ całej treści dyrektywy przebija obawa przed szkodliwymi skutkami, jakie mogą nieść usługi audiowizualne dla poszczególnych osób i dla ich rodzin. Dlatego też ustawodawca europejski zwraca uwagę na potrzebę upowszechniania umiejętności korzystania z mediów we wszystkich grupach społecznych, widząc potrzebę stałego monitorowania i rozwijania tych umiejętności. Wyraźnie wskazano w dyrektywie na konieczność stałego kształcenia nauczycieli i szkoleniowców, potrzebę specjalnych szkoleń internetowych dla dzieci oraz zajęć otwartych dla rodziców. Podkreślono

w państwie członkowskim, w którym ma swoją siedzibę". Sprawa C-56/96 VT4, pkt 22; sprawa C-212/97 Centros przeciwko Erhvers-og Selskabsstryrelsen; zob. również: sprawa C-11/95 Komisja przeciwko Królestwu Belgii oraz sprawa C-14/96 Paul Denuit.

${ }^{21}$ Sprawa C-355/98 Komisja przeciwko Belgii [2000]; sprawa C-348/96 Calfa [1999]. 
potrzebę organizowania krajowych kampanii społecznych na temat jak odpowiedzialnie korzystać $\mathrm{z}$ internetu ${ }^{22}$.

W dyrektywie podkreślono, że prawa do rozpowszechniania telewizyjnego wydarzeń budzących duże zainteresowanie odbiorców mogą być nabywane przez nadawców na zasadzie wyłączności. Zauważono jednak, że istotne jest przy tym to, aby promować pluralizm dzięki różnorodności źródeł i rozmaitości oferty informacyjnej. Wskazano przy tym na konieczność przestrzegania zasad wolności środków przekazu, na straży których stoi art. 11 Karty Podstawowych Praw Unii Europejskiej. Jest rzeczą ciekawą, że pominięto zupełnie potrzebę uwzględnienia standardów wypracowanych przez Radę Europy na gruncie art. 10 Europejskiej Konwencji o Ochronie Praw Człowieka i Podstawowych Wolności w tym także tych, które określił Trybunał Praw Człowieka w Strasburgu. Warto zauważyć, że w chwili obecnej Unia nadal nie jest członkiem Europejskiej Konwencji, aczkolwiek nie ma chyba przeszkód, aby standardy strasburgskie recepować na gruncie unijnym. Dość stanowczo ustawodawca unijny opowiada się jednak za tym, aby na uczciwych, rozsądnych i niedyskryminujących zasadach, z należytym uwzględnieniem praw wyłącznych udzielać nadawcom, którzy nie mają wyłączności możliwości wykorzystywania krótkich fragmentów tych wydarzeń, które budzą powszechne zainteresowanie opinii publicznej. W dyrektywie stwierdzono, że nadawca powinien mieć możność skorzystania z takiej możliwości wykorzystania krótkiego fragmentu na użytek ogólnych audycji informacyjnych poprzez pośrednika reprezentującego go w konkretnych przypadkach. Wskazał, że takie krótkie fragmenty odnoszące się do wydarzeń budzących duże zainteresowanie odbiorców mogą być wykorzystane przez wszystkie kanały, w tym także specjalne kanały sportowe, do celów przekazu obejmującego obszar całej Unii Europejskiej. Stwierdzono przy tym, że czas trwania takich fragmentów nie powinien przekraczać 90 sekund. Podkreślono w dyrektywie, że prawo dostępu do krótkich fragmentów wydarzeń powinno być stosowane w oparciu o zasadę transgraniczną tylko wtedy, gdy jest to konieczne. Regułą powinno być to, że nadawca najpierw ubiega się o dostęp do krótkich fragmentów u tego nadawcy krajowego, który dysponuje prawami wyłącznymi do transmisji wydarzenia budzącego duże zainteresowanie odbiorców, który ma siedzibę w tym samym, co dany nadawca, państwie członkowskim ${ }^{23}$. Ustawodawca europejski widzi niebezpieczeń-

22 Wskazano na to już w zaleceniu Parlamentu Europejskiego i Rady z 20 grudnia 2006 r. w sprawie ochrony małoletnich, godności ludzkiej oraz prawa do odpowiedzi w odniesieniu do konkurencyjności europejskiego przemysłu audiowizualnego oraz internetowych usług informacyjnych. Dz. U. L. 378 z 27 grudnia 2006 r., s. 72.

${ }_{23} \mathrm{~W}$ dyrektywie zawarowano, że zasada kraju pochodzenia ma zastosowanie zarówno do dostępu do krótkich fragmentów wydarzeń budzących duże zainteresowanie odbiorców, jak i do pełnych transmisji. Oznacza to, że przepisy prawa muszą być stosowane w pewnej kolejności. W zakresie dostępu do krótkich fragmentów powinno mieć zastosowanie prawo państwa członkowskiego, w którym siedzibę ma nadawca oferujący sygnał pierwotny, tj. udzielający dostępu. Zwykle - jak zauważono - jest to państwo, w którym odbywa się przedmiotowe wydarzenie. W przypadku, gdy państwo członkowskie ustanowiło równoważny system udzielania dostępu, zastosowanie powinno mieć prawo tego państwa członkowskiego. Do transmisji krótkich fragmentów ma mieć przy tym zastosowanie prawo państwa członkowskiego, w którym siedzibę ma nadawca transmitujący. Wyraźnie podkreślono, że wymogi dyrektywy dotyczące dostępu do wydarzeń budzących duże zainteresowanie odbiorców, w celu przygotowania krótkich relacji informacyjnych, nie naruszają dyrektywy 2001/29/WE Parla- 
stwo kompilowania z krótkich fragmentów audycji służących celom rozrywkowym i sprzeciwia się takiej możliwości.

W dyrektywie zobowiązano państwa unijne do tego aby dostawcy usług medialnych, którzy wyemitowali na żywo telewizyjne audycje informacyjne, mogli w dalszym ciągu udostępniać je po transmisji na żywo w formie usługi na żądanie, i aby nie musieli dokonywać zmian w poszczególnych audycjach poprzez usuwanie krótkich fragmentów. (Chodzi tu o to, aby nie naruszyć przy tej okazji praw autorskich, bądź praw artystów wykonawców.) Jak zauważono, możliwość taka powinna być ograniczona do sytuacji, w której ten sam dostawca usług medialnych udostępnia identyczne audycje telewizyjne w formie usługi na żądanie. Ma to zapobiec tworzeniu nowych rodzajów usług na żądanie, opartych na krótkich fragmentach.

Ustawodawca europejski podkreślił w treści dyrektywy, że audiowizualne usługi medialne na żądanie różnią się od usług przekazu telewizyjnego możliwościami wyboru i kontroli, a także wpływem jaki wywierają na społeczeństwo. Uzasadniać ma to objęcie audiowizualnych usług medialnych na żądanie węższym zakresem regulacji, co oznacza, że powinny one być zgodne z podstawowymi zasadami określonymi w dyrektywie. Bardzo ważną rzeczą jest, aby użytkownicy (odbiorcy usług audiowizualnych) wiedzieli dokładnie kto odpowiada za treść tych usług. Dlatego też zadaniem państw członkowskich jest dopilnowanie - oczywiście przez właściwe regulacje prawne - aby takowi odbiorcy, użytkownicy usług, mieli nieprzerwanie łatwy i bezpośredni dostęp do informacji na temat dostawcy usługi medialnej. Wskazano przy tym, że niezbędne jest wprowadzenie przypisów służących ochronie fizycznego, umysłowego i moralnego rozwoju małoletnich oraz ochronie godności ludzkiej we wszystkich audiowizualnych usługach medialnych, w tym także w handlowych przekazach audiowizualnych. Podnosząc to, stwierdzono jednak, że należy zachować równowagę pomiędzy środkami służącymi ochronie fizycznego, umysłowego i moralnego rozwoju małoletnich oraz ochronie godności ludzkiej, a podstawowym prawem do wolności słowa, zawartym w Karcie Praw Podstawowych Unii Europejskiej ${ }^{24}$.

Twórcy dyrektywy zdawali sobie wyraźnie sprawę, że audiowizualne usługi medialne na żądanie mogą w przyszłości, przynajmniej częściowo, zastapić rozpowszechnianie telewizyjne. W związku z tym, w treści dyrektywy podkreślono konieczność wspierania produkcji i dystrybucji utworów europejskich oraz potrzebę aktywnego przyczyniania się do promowania różnorodności kulturowej. Wskazano, że następować

mentu Europejskiego i Rady z dnia 22 maja 2001 r. w sprawie harmonizacji niektórych aspektów praw autorskich i pokrewnych w społeczeństwie informacyjnym. Dz. U. L. 167 z 22 czerwca 2001 r., s. 10. Nie naruszają też one odpowiednich konwencji międzynarodowych w dziedzinie ochrony praw autorskich i praw pokrewnych.

${ }_{24}$ Jako przykładowe środki, wskazano stosowanie osobistych numerów identyfikacyjnych (kodów PIN), systemów filltrowania lub oznaczania. Dyrektywa podkreśla przy tym, że na znaczenie tych systemów zwrócono już uwagę w zaleceniu w sprawie ochrony małoletnich, godności ludzkiej oraz prawa do odpowiedzi. W treści dyrektywy zauważono także, że do dostawców usług medialnych, którzy podlegają jurysdykcji państw członkowskich ma zastosowanie zakaz rozpowszechniania pornografii dziecięcej, zgodnie z przepisami decyzji ramowej Rady 2004/68/WSiSW z dnia 22 grudnia 2003 r. dotyczącej zwalczania seksualnego wykorzystywania dzieci i pornografii dziecięcej. Dz. U. L. 13 z 20 stycznia 2004 r., s. 44. 
to może w formie udziału finansowego takich usług medialnych w produkcji utworów europejskich, zakupu praw do nich, zapewnieniu ich minimalnego udziału w katalogu usług wideo na żądanie, lub prezentowaniu ich w sposób atrakcyjny w elektronicznym przeglądzie audycji. Podkreślono przy tym regularne weryfikowanie, stosowanie przepisów dotyczących wspierania utworów europejskich przy pomocy audiowizualnych usług medialnych.

W dyrektywie podjęto próbę zdefiniowania pojęcia „producenta niezależnego od nadawcy", którym posługuje się m.in. w art. 5 dyrektywa 89/552/EWG stwierdzając, że państwa członkowskie, którym pozostawiano sformułowanie takich definicji, powinny uwzględniać takie kryteria, jak to kto jest właścicielem firmy producenckiej, ile audycji jest dostarczanych samemu nadawcy oraz kto posiada prawa do wtórnego wykorzystywania audycji. Zauważono przy tym, że państwa członkowskie powinny zachęcać nadawców do przyznania należytego udziału w ofercie programowej „koprodukcjom europejskim i europejskim utworom pochodzenia nieeuropejskiego" (sic!!!).

Warto zauważyć szczególnie w sytuacji, kiedy w Polsce toczy się dyskusja o zbyteczności prawa do odpowiedzi i sprostowania, iż dyrektywa wyraźnie podkreśliła, że prawo do odpowiedzi jest właściwym środkiem prawnym w przypadku rozpowszechniania telewizyjnego i może być stosowane także w odniesieniu do usług elektronicznych. Rzeczą państw członkowskich jest wprowadzenie do prawa krajowego rozwiązań gwarantujących możliwość skorzystania z tego prawa w odniesieniu do mediów elektronicznych. W dyrektywie podkreślono, że rozwój nowych technik reklamy i innowacje marketingowe stworzyły nowe skuteczne możliwości zamieszczania audiowizualnych przekazów handlowych w ramach tradycyjnych usług rozpowszechniania, dzięki czemu przekazy te mogą w tych samych warunkach lepiej konkurować z innowacyjnymi usługami na żądanie ${ }^{25}$. Zaakcentowano także, że w interesie publicznym reklama telewizyjna, telesprzedaż i lokowanie produktu winno być dozwolone pod jasno sprecyzowanymi warunkami, przy czym lokowanie produktu mające charakter ukryty powinno zostać zakazane. Zasadą winno być oddzielenie reklam od audycji. W dyrektywie podkreślono, że nowe technologie dają widzom większą możliwość unikania reklamy, podkreślając, że dyrektywa ta nie dopuszcza zwiększania limitu reklam emitowanych w ciagu godziny, daje jednak nadawcom większą elastyczność w ich zamieszczaniu, o ile nie narusza to nadmiernie integralności. Wskazano, że dyrektywa ogranicza możliwość przerywania reklamami utworów kinematograficznych i filmów wyprodukowanych dla telewizji oraz niektórych kategorii audycji wymagających specjalnej ochrony. Zauważono także, że ważniejszy od dziennego limitu reklamy telewizyjnej jest limit godzinowy, dlatego zalecono, aby wprowadziły go państwa członkowskie. Podniesiono przy tym, że kanały telesprzedażowe lub reklamowe wydają się nie mieć uzasadnienia ${ }^{26}$. W dyrektywie zakazano procedury ukrytego handlowego przekazu au-

25 Stwierdziła to już wcześniej Komisja w komunikacie wyjaśniającym poświęconym niektórym aspektom przepisów o reklamie telewizyjnej, zawartych w dyrektywie o telewizji bez granic. Dz. U. C. 102 z 28 kwietnia 2004 r., s. 2.

${ }^{26}$ Podkreślono, iż limit spotów reklamy telewizyjnej i spotów telesprzedażowej, wynoszący $20 \%$ godziny zegarowej, pozostaje w mocy, zauważając, że pod pojęciem spotu reklamowego należy rozumieć reklamę telewizyjną - w znaczeniu art. 1 lit. I dyrektywy 89/552/EWG - trwającą nie dłużej niż 12 minut. 
diowizualnego, stwierdzając, że ma on negatywny wpływ na konsumentów, tj. tzw. lokowania produktu ${ }^{27}$. Ustawodawca europejski stwierdził, iż państwa członkowskie winny zakazać sponsorowania, prezentacji produktu i jego lokowania w przypadkach, gdy te zabiegi wpływają na treść audycji w sposób naruszający odpowiedzialność i niezależność redakcyjną dostawcy usług medialnych.

W treści dyrektywy, zmieniając dyspozycję art. 1a dyrektywy 89/552/EWG, zdefiniowano pojęcie usługi audiowizualnej, stwierdzając, że usługą taką w rozumieniu art. 49 i 50 Traktatu, jest usługa, za którą odpowiedzialność redakcyjną ponosi dostawca usług medialnych, i której podstawowym celem jest dostarczanie ogółowi odbiorców poprzez sieci łączności elektronicznej, audycji w celach informacyjnych, rozrywkowych lub edukacyjnych. Zawarowano, że taka audiowizualna usługa medialna, jest przekazem telewizyjnym albo audiowizualną usługą medialną na żądanie. W treści dyrektywy zdefiniowano także pojęcia: audycji, odpowiedzialności redakcyjnej, dostawcy usług medialnych, rozpowszechniania telewizyjnego, nadawcy, audiowizualnej usługi medialnej na żądanie, lądowego przekazu audiowizualnego, reklamy telewizyjnej, ukrytego przekazu audiowizualnego, sponsorowania, telesprzedaży, lokowania produktów oraz utworu europejskiego. Określono także w dyrektywie ponownie zasady rozmieszczenia reklam, czas ich nadawania i zasady przerywania audycji i programów reklamami. Regulacje te zmuszą niewątpliwie państwa członkowskie, w tym i Polskę, do zmian rozlicznych przepisów prawa wewnętrznego. W przypadku Polski, niewątpliwie będą to odpowiednie przepisy ustawy o radiofonii i telewizji, a także prawa autorskiego. Warto przy okazji zauważyć, że ustawodawca europejski stara się chronić interesy państw członkowskich, wskazując iż mogą one zobowiązywać dostawców usług medialnych do przestrzegania bardziej szczegółowych lub surowszych przepisów w dziedzinach, które podlegają koordynacji z mocy dyrektywy, pod warunkiem, że przepisy stanowione przez państwa członkowskie będą zgodne z prawem wspólnotowym. Wyraźnie zezwolono państwom członkowskim, aby w razie stwierdzenia, że określony nadawca ustanowił swoją siedzibę w państwie członkowskim, sprawującym jurysdykcję, w celu ominięcia surowszych przepisów - mogły one podjać odpowiednie środki przeciwko takiemu nadawcy. Środki takie muszą być przy tym obiektywnie niezbędne, stosowane w sposób niedyskryminacyjny i proporcjonalne do zamierzonych celów. Należy zauważyć, że na państwa członkowskie został nałożony obowiązek wdrożenia przepisów dyrektywy do dnia 19 grudnia 2009 r. i niezwłocznego przekazania Komisji tekstu tych przepisów. Zobowiązano także państwa członkowskie, aby doprowadziły do sytuacji, w której dzięki audiowizualnym usługom medialnym świadczonym na żądanie przez dostawców usług medialnych,

27 Pod pojęciem lokowania produktu, dyrektywa rozumie, dowolną formę handlowego przekazu audiowizualnego, polegającą na tym, że w zamian za opłatę lub podobne wynagrodzenie w audycji przedstawia się produkt, usługę lub znak towarowy, ewentualnie nawiązuje się do nich tak, że stanowią one element samej audycji. Podkreślono przy tym, że bezpłatne dostarczenie towarów lub usług, takich jak rekwizyty lub nagrody należy traktować jako lokowanie produktu jednie wtedy, gdy dane towary lub usługi mają znaczną wartość. Podniesiono wreszcie, że lokowanie produktu powinno podlegać takim samym przepisom i ograniczeniom jakościowym, jak handlowy przekaz audiowizualny. Decydującym kryterium pozwalającym rozróżnić sponsorowanie od lokowania, jest to, że w przypadku lokowania odwołanie do danego produktu zostaje wbudowane $\mathrm{w}$ akcję audycji. 
podlegających ich jurysdykcji, promowana była (w granicach możliwości i w stosowny sposób) produkcja utworów europejskich. W tym przedmiocie państwa członkowskie mają obowiązek złożenia sprawozdania do dnia 19 grudnia 2011 roku, a następnie co 4 lata.

Dyrektywa 2007/65/WE Parlamentu Europejskiego i Rady z dnia 11 grudnia 2007 r. należy niewątpliwie do aktów normatywnych niezmiernej wagi, gdyż bardzo głęboko reguluje prawa i obowiązki nadawców, w tym także podmiotów na które nie zwracano dotychczas należytej uwagi, a mianowicie dostawców usług medialnych, także tych, którzy są dostawcami usług medialnych, mających formę przekazu telewizyjnego. Jest rzeczą oczywista, że trwałość przyjętych rozwiązań w dużej mierze zależna będzie jednak od rozwoju techniki i jakiekolwiek prognozy w tym zakresie są trudne do sformułowania. 
